NBER WORKING PAPER SERIES

\title{
CONTRIBUTIONS TO DEFINED CONTRIBUTION PENSION PLANS
}

\author{
James J. Choi \\ Working Paper 21467 \\ http://www.nber.org/papers/w21467 \\ NATIONAL BUREAU OF ECONOMIC RESEARCH \\ 1050 Massachusetts Avenue \\ Cambridge, MA 02138 \\ August 2015
}

I thank the National Institutes of Health (grant R01-AG-021650) for financial support of the writing of this article. This article was prepared for the Annual Review of Financial Economics. Posted with permission from the Annual Review of Financial Economics, Volume 7 (C 2015 by Annual Reviews, http://www.annualreviews.org. DOI: 10.1146/annurev-financial-111914-041834. I periodically give compensated talks on behavioral economics and retirement savings to institutions that administer or sponsor retirement savings plans. The views expressed herein are those of the author and do not necessarily reflect the views of the National Bureau of Economic Research.

NBER working papers are circulated for discussion and comment purposes. They have not been peerreviewed or been subject to the review by the NBER Board of Directors that accompanies official NBER publications.

(C) 2015 by James J. Choi. All rights reserved. Short sections of text, not to exceed two paragraphs, may be quoted without explicit permission provided that full credit, including $(\mathrm{C}$ notice, is given to the source. 
Contributions to Defined Contribution Pension Plans

James J. Choi

NBER Working Paper No. 21467

August 2015, Revised October 2016

JEL No. D14,J32

\begin{abstract}
Defined contribution (DC) pensions are an increasingly important means of financing retirement consumption. Because individuals often have substantial discretion over how much is contributed to their DC pension, studying DC contribution choices provides general insights into the determinants of individual economic decision-making. The literature has found strong deviations from many predictions of classical frictionless optimizing models. I provide an overview of the U.S. DC pension system and review the literature on the effect of matching contributions, automatic enrollment, active choice deadlines, choice overload, financial literacy, peer effects, mental accounting, and personal experience on individuals' DC contributions.
\end{abstract}

James J. Choi

Yale School of Management

165 Whitney Avenue

P.O. Box 208200

New Haven, CT 06520-8200

and NBER

james.choi@yale.edu 


\section{Introduction}

In 13 B.C., the Roman emperor Augustus-concerned that retired veterans would revolt if they were impoverished-established a retirement benefit for all Roman soldiers. After 16 years in a legion and four years in the military reserves, legionaries would receive a one-time payment fixed at 3,000 denarii (thirteen times their annual salary), while centurions would receive a higher one-time amount. For most of the twentieth century, the Augustan model of using a fixed formula to determine payments to retirees was dominant among retirement benefit plans. Plans that use such a formula are called defined benefit (DB) pensions. In 1974, the assets that funded DB pension promises constituted $\$ 256$ billion out of the $\$ 369$ billion in total U.S. retirement assets (Investment Company Institute 2014). Unlike the Augustan pension, modern DB pensions typically make a stream of regular payments for the duration of the pensioner's life (and perhaps also that of the pensioner's beneficiary) rather than a single up-front payment.

In recent decades, however, defined contribution (DC) pensions have increased greatly in importance. The payouts of DC pensions are not determined by formula. Instead, contributions are made to an investment account during the working years, and the individual can withdraw money from the account's balance during retirement. The sum of the contributions and the earnings and capital gains they accrue determines the total amount that can be withdrawn. In June 2014, U.S. assets in Individual Retirement Accounts (IRAs) and employer-sponsored DC plans totaled $\$ 13.8$ trillion, far exceeding the \$8.3 trillion in DB plans (Investment Company Institute 2014). Only 16\% of U.S. private industry workers participated in a DB plan, whereas $42 \%$ of private industry workers participated in an employer-sponsored DC plan and 38\% of all U.S. households owned an IRA (Holden and Schrass 2013; United States Department of Labor 2013). Across the OECD, the share of DC assets increased from 2001 to 2012 in seven countries and decreased in none of the other nine for which data are available (OECD 2013).

Research on DC pensions has attracted wide interest not only because of DC pensions' critical role in determining the economic security of the elderly, but also because individuals often choose the savings rates and asset allocations in their own DC accounts. Therefore, studying individual choices in DC accounts illuminates how individuals make 
economic decisions in general. The literature documents strong deviations from the predictions of classical rational models, which has motivated employers and governments to take a more active role in designing DC pensions that nudge individuals towards better outcomes through their "choice architecture" (Thaler and Sunstein 2008)—the context in which people make decisions. Whereas the initial transition from a DB-dominant to a DC-dominant system drastically shifted responsibilities for pension contribution and asset allocation decisions from professional investment managers to individuals, the "nudge" movement is a partial retreat towards a middle ground where DC savers are given a great deal of autonomy but have their choices deliberately guided by professionally crafted choice architecture.

This review begins by describing features of DC pensions in the U.S. I then discuss determinants of individual DC contribution choices, focusing on the U.S. evidence. Due to space constraints, I will not review the important literature on asset allocation decisions in DC plans, and I will only briefly touch on the literature on the extent to which DC contributions crowd out savings elsewhere in the household balance sheet.

\section{The varieties of DC pensions in the U.S.}

The Investment Company Institute (2014) reports that in June 2014, U.S. retirement assets totaled $\$ 24.0$ trillion, which constituted 36\% of all U.S. household financial assets. $\$ 6.6$ trillion was held in DC plans sponsored by employers, and $\$ 7.2$ trillion was held in IRAs. The remainder of the retirement assets was held in private-sector DB plans (\$3.2 trillion), state and local government DB plans (\$3.7 trillion), federal government DB plans ( $\$ 1.4$ trillion), and annuities (\$2.0 trillion).

Sixty-seven percent of employer-sponsored DC plan assets were in 401(k) plans, and another $14 \%$ were in 403 (b) plans, which are similar to $401(\mathrm{k})$ plans but available only to employees of certain public schools, employees of certain non-profit organizations, and certain religious ministers. Six percent were in the Federal Employees Retirement System Thrift Savings Plan, which is a 401(k)-like plan for federal government employees. The remaining $12 \%$ of assets were split among 457 plans and other DC plans (profit-sharing plans, thrift-savings plans, stock bonus plans, and money purchase plans) without $401(\mathrm{k})$ features. 
Contributions to an employee's 401(k) are made via deduction from the employee's paycheck. Typically, either a percentage of the employee's paycheck or an absolute dollar amount per paycheck is designated as the amount to be contributed each pay cycle. This same percentage or absolute amount is automatically deducted from each subsequent paycheck until the employee changes her contribution election or leaves the firm. The employer may also make contributions.

The most common type of employee 401(k) contribution is the before-tax contribution, which reduces taxable income in the year of the contribution by the amount contributed. At withdrawal, the full principal, dividends, interest, and capital gains constitute ordinary taxable income. Less common is the after-tax contribution, which provides no tax deduction in the year of the contribution. Dividends, interest, and capital gains accrue tax-free until withdrawal, when dividends, interest, and capital gains but not principal are ordinary taxable income. A more recently introduced option is the Roth contribution, which also provides no tax deduction in the year of the contribution. However, none of the withdrawn amount is taxed in most circumstances. For most 401(k) plans in 2014, the total allowable employee pre-tax plus Roth contribution in a single calendar year was $\$ 17,500$ for those under age 50 and $\$ 23,000$ for those 50 and older. The total employee plus employer contributions in a calendar year could not exceed \$52,000 for employees under age 50 and $\$ 57,500$ for employees 50 and older. Withdrawals of 401(k) balances before age $591 / 2$ can only be made under certain circumstances and usually incur a tax penalty.

In order to contribute to a 401(k) or 403(b) plan, one must work for an employer that offers such a plan. Copeland (2013) reports that in 2012, 59\% of nonagricultural wage and salary workers age 16 and over had a "salary reduction plan" (a category that consists predominantly of 401(k) and 403(b) plans) available at their workplace, a substantial increase from $27 \%$ in 1988. Conditional on availability, the fraction of eligible employees who participate in a salary reduction plan rose from 57\% in 1988 to $73 \%$ in 2012. Among those who participate in a salary reduction plan, the average percent of annual earnings contributed by the employee to the plan increased from $6.6 \%$ in 1988 to $7.5 \%$ in 2006 , but then fell to $7.4 \%$ in 2009 and $6.7 \%$ in 2012. Poterba et al. (2010) find that in 2003, employer contributions to 401(k) participants' accounts averaged $4.6 \%$ of 
participant earnings. Higher-income families are much more likely to have access to a 401(k) plan than lower-income families, but there is not much of an age gradient in 401(k) eligibility. Vanguard (2014) provides many statistics on how 401(k) usage varies by demographic group.

IRAs are tax-advantaged savings accounts that are usually not sponsored by employers. The Investment Company Institute (2014) reports that at year-end 2013, employer-sponsored IRAs-SEP, SAR-SEP, and SIMPLE IRAs-contained only $6 \%$ of total IRA assets. Eighty-six percent of IRA assets were held in traditional IRAs, and the remaining 7\% in Roth IRAs, which were first made available in 1998. The sum of traditional and Roth IRA contributions in 2014 could not exceed \$5,500 for those younger than 50 and $\$ 6,500$ for those 50 and older. Contributions to traditional IRAs are taxdeductible in the year of the contribution, but this tax deductibility phases out at higher incomes for households covered by an employer-sponsored retirement plan. The entire withdrawal from traditional IRAs (except for principal from non-deductible contributions) is taxed as ordinary income. Contributions to Roth IRAs are not tax-deductible, but withdrawals are not taxed under most circumstances. Assets can also be "rolled over" into an IRA from the DC plan of a former employer without triggering taxation or penalties. There is no upper limit on the rollover amount. Withdrawals from IRAs are allowed at any time, but withdrawals before age 591/2 usually incur a tax penalty.

The vast majority of IRA balances are the result of rollovers from the DC plans of former employers. In 2010, rollovers constituted $90 \%$ of flows into traditional and Roth IRAs (Investment Company Institute 2014). Holden and Schrass (2013) report that although most U.S. households are eligible to make IRA contributions, only $15 \%$ contributed to an IRA in tax year 2012. Among those who did contribute to an IRA, 52\% contributed to a traditional IRA, $40 \%$ contributed to a Roth IRA, and $23 \%$ contributed to an employer-sponsored IRA. Conditional on contributing, the median contribution to a traditional IRA was $\$ 4,000$, as was the median contribution to a Roth IRA. 


\section{Matching contributions}

\section{A. Institutional details}

Many employers make matching contributions to their 401(k) or 403(b) employer contributions that are proportional to the individual employee's contribution up to a threshold. Vanguard (2014), a major DC plan record keeper, reports that $83 \%$ of its employer-sponsored plans offered matching contributions in 2013. Thirty-four percent of its plans provided both a matching contribution and an additional employer contribution that is not contingent on the employee contribution, and $8 \%$ of its plans provided only a non-matching employer contribution. The most common matching formula, adopted by $25 \%$ of Vanguard plans, is a $50 \%$ match on the first $6 \%$ of the employee's pay contributed. Among plans with matches, about three quarters have a single-tier formula, which applies the same match rate up to the threshold. About a fifth have a multi-tier formula, such as a $100 \%$ match on the first $3 \%$ of pay contributed and a $50 \%$ match on the next $2 \%$ of pay contributed. The remainder have formulas based on age, tenure, or other variables. ${ }^{1}$

Matching contributions vest immediately in $45 \%$ of Vanguard plans. Employees who leave their employer before becoming fully vested will forfeit some or all of their match balances. The most common delayed vesting schedule is a five-year graded schedule, adopted by $19 \%$ of plans, which gradually increases the fraction of match balances an employee can retain upon departure until she attains five years of tenure at the company, at which point she can keep $100 \%$ of the match. Fourteen percent of plans have a sixyear graded schedule, and $10 \%$ have a three-year cliff schedule, where the employee can retain none of her match if she leaves before attaining three years of tenure and all of her match afterwards.

Employers usually adopt matches in order to encourage employees to save in the DC plan. They do this not only out of a sense of benevolent paternalism, but also because the IRS's non-discrimination test on 401(k) plans limits the amount by which contributions of highly compensated employees may exceed those of non-highly compensated

\footnotetext{
${ }^{1}$ Dworak-Fisher (2011) calculates similar proportions using the nationally representative National Compensation Survey data from 2002 and 2003: 82\% of plans with matches have a single-tier formula, and 13\% have a multi-tier formula.
} 
employees. ${ }^{2}$ Therefore, in order to deliver the full benefits of a 401(k) plan to highly compensated employees, the employer must make sure that rank-and-file employees' contributions are not too low.

\section{B. Effects on DC pension participation}

Standard economic theory predicts that in a two-period setting, a higher match rate on the first dollar contributed will increase via a substitution effect the fraction of employees who contribute to the DC plan. This is because, for somebody who would not participate in the plan without the match, the match increases the opportunity cost of allocating the marginal dollar to current consumption or saving outside the DC plan instead of saving inside the DC plan. Unless there are significant fixed costs to joining the plan, match rates on additional dollars contributed should not affect the plan participation decision.

Empirically identifying the causal impact of matches on employee contributions is challenging because the match employees face is likely to be correlated with their unobserved taste for saving. On the one hand, matches may be more generous among workforces with a low taste for saving if matches are more likely to be adopted by employers having trouble satisfying the IRS non-discrimination test. On the other hand, employees with a high taste for saving may sort into employers with generous matches, since savings-related benefits are more attractive to such employees. If one uses the crosssectional relationship between matches and employee contributions as an estimate of the causal impact of the match, the first source of endogeneity downwardly biases this estimate, whereas the second upwardly biases it.

Studies that use purely cross-sectional variation to estimate match effects on plan participation rates uniformly find that matches increase participation (Andrews 1992; Papke and Poterba 1995; United States General Accounting Office 1997; Clark and Schieber 1998; Basset et al. 1998; Clark et al. 2000; Even and Macpherson 2005; Engelhardt and Kumar 2007; Huberman et al. 2007; Mitchell et al. 2007; Dworak-Fisher 2011). Many of these papers use measures of match generosity that are not the theoretically rel-

\footnotetext{
${ }^{2}$ Less stringent non-discrimination testing rules apply to 403(b) plans.
} 
evant match rate on the first dollar contributed ${ }^{3}$, such as a binary indicator for the presence of a match, or the ratio of aggregate employer contributions (some of which are nonmatching contributions) to aggregate employee contributions (some of which are unmatched). Hence, the magnitudes of the effects they estimate are hard to interpret. Among studies that do relate participation to the first-dollar match rate without employing instrumental variable methods, a 10 percentage point increase in the match rate is associated with a participation rate increase of 2.5 percentage points (Papke and Poterba 1995), 6.3 percentage points (Clark and Schieber 1998), 3 percentage points (Clark et al. 2000), and 2 percentage points (Engelhardt and Kumar 2007). Basset et al. (1998) find that the presence of a match is associated with a 9 percentage point higher participation rate, but there is no difference in participation across plans with different positive firstdollar match rates. This latter null relationship may be due to their using surveyed individuals' recollections of their first-dollar match rate as the explanatory variable, which creates a great deal of measurement error. Choi et al. (2011) find that at one large company, far less than half of employees were able to correctly state their plan's match rate and match threshold.

Dworak-Fisher (2011) uses cross-sectional data but utilizes instrumental variables to correct for the endogeneity of the match. The instruments for the first-dollar match that workers face are their coworkers' characteristics and the match generosity of other firms in their employer's labor market. The validity of these instruments relies on an absence of significant peer effects on saving (see Section 6) and a lack of homophily with respect to savings preferences (i.e., workers with a high taste for saving do not tend to work with or near others with a high taste for saving). He finds that the instrumental variable treatment estimates are larger than the OLS estimates, implying that matches are more generous for workforces with a lower taste for saving. Roughly speaking, a 10 percentage point increase in the first-dollar match rate increases the participation rate by between 2 and 4 percentage points.

An alternative approach to addressing the correlation between the match and unobserved savings preferences is to use within-firm variation in the match over time. Pap-

\footnotetext{
${ }^{3}$ This first-dollar match rate should also in theory be adjusted for the vesting schedule and how likely employees are to reach vesting milestones.
} 
ke (1995) finds no participation response to plan-level changes in the aggregate employer to employee contribution ratio between 1986 and 1987. Kusko et al. (1998) study a firm whose match rate took on four different values between $0 \%$ and $150 \%$ in the course of only four years. They too find that participation rates barely move in response to match rate changes. There is no change in the participation rate when the match rate increases from $65 \%$ to $150 \%$, and only a 6 percentage point drop when the match rate drops from $139 \%$ to $0 \%$. Choi et al. (2002) compare the participation behavior of employees hired before the introduction of a $25 \%$ first-dollar match rate to those hired afterwards. For 40year-old males, they find a 3.4 percentage point increase in participation at three to four months of job tenure. Consistent with the theoretical prediction in a two-period setting, there is no change in participation rates at another firm that kept its first-dollar match rate unchanged but increased its match threshold by $2 \%$ of income. One shortcoming of identifying match effects from high-frequency fluctuations in the match is that $401(\mathrm{k})$ contributions exhibit a great deal of inertia (see Section 4). Therefore, small short-run reactions to a match change may not be representative of the asymptotic participation rate reaction.

A third approach to identifying match effects is to randomize the match offered to individuals within a field experiment. Duflo et al. (2006) randomly assigned customers of the tax preparer H\&R Block to receive a $0 \%, 20 \%$, or $50 \%$ match on contributions to an IRA administered by H\&R Block. During the course of each tax preparation session, H\&R Block's tax software prompted the tax professional to ask the customer whether she wanted to contribute to the IRA. The match was presented as a one-time take-it-or-leaveit offer on immediate contributions to the IRA, which could be made out of the customer's forthcoming tax refund. Tax professionals could choose-before they learned the match rate assignment - not to ask the customer about the IRA, and about $25 \%$ of customers in each treatment arm did not receive an offer. Averaging over customers who did and did not receive the IRA offer, take-up of the IRA was $3 \%, 8 \%$, and $14 \%$ respectively as the match rose from $0 \%$ to $20 \%$ to $50 \%$. Although the experiment's setting is quite different from both the 401(k) setting and the typical IRA setting, the finding of an approximately 2 percentage point increase in participation per 10 percentage point increase in the match rate is remarkably similar to the non-experimental estimates from the $401(\mathrm{k})$ literature. 
Even when match terms are extremely generous, a large fraction of employees do not participate in the 401(k). Choi et al. (2010) point out that for employees over age $59^{1} / 2$, not contributing up to the $401(\mathrm{k})$ match threshold can create an unexploited arbitrage opportunity. Because employees over $59 \frac{1}{2} 2$ often can withdraw their $401(\mathrm{k})$ balances without restrictions or penalties, contributing less than the match threshold is dominated by a strategy that increases the contribution rate to the match threshold, reaps the match, and then immediately withdraws the incremental contribution. Nevertheless, $36 \%$ of match-eligible employees over 591/2 in their sample of seven firms leave arbitrage profits on the table, often because they fail to contribute anything at all to the 401(k). Duflo et al. (2006) also find that practically none of the customers in their experiment execute a similar "deposit and immediately withdraw" strategy.

\section{Effects on DC pension contribution rates}

Employers and policymakers care not only about what fraction of the population contributes to a DC plan, but also the amount that is contributed. Standard theory gives no clear prediction about how matches should affect the average employee contribution rate. For employees who would contribute nothing without the match, the substitution effect should increase their contributions. For employees who would contribute a positive amount below the match threshold without the match, there are offsetting substitution and income effects. The income effect arises from the match increasing these employees' lifetime resources if they left their contribution rate unchanged. The income effect should suppress saving under the typical assumption that current consumption is a normal good. The contributions of employees who would contribute at or above the match threshold should fall. These employees earn the match on all their below-threshold contributions, triggering an income effect, but the return on their marginal dollar of saving is unaffected, so there is no substitution effect. The effect of a match in a population will depend not only on the relative sizes of its income and substitution effects, but also on the distribution of its contribution rates absent the match.

Besides the previously discussed problems with the endogeneity of the match, the empirical study of match effects on average contribution rates is complicated by the fact that the match is a policy with three dimensions: the match rate(s), the match threshold(s), and the vesting schedule. Theory predicts that the effect of a $200 \%$ match on the 
first $1 \%$ of income contributed could be very different from the effect of a $200 \%$ match on the first $4 \%$ of income contributed or a $50 \%$ match on the first $4 \%$ of income contributed. Moreover, the effects of the match rate and the match threshold are not additively separable; for example, raising the match threshold from $2 \%$ to $6 \%$ of income would have little effect if the match rate were $0.1 \%$, whereas it might have a large effect if the match rate were $100 \%$. Studies nevertheless often treat the match as a one-dimensional object, summarizing it using variables such as the match rate on the first dollar contributed or the ratio of aggregate employer contributions to aggregate employee contributions.

Studies also often focus on the match's effect on the average contribution rate conditional on contributing a positive amount. But this conditional average is usually not an object of policy interest, whereas the unconditional average is. A match that succeeds in raising the unconditional average contribution rate of the population might cause the average contribution rate among contributors to fall by inducing employees with weak savings motives to enter the pool of contributors at low contribution rates. In addition, some studies report associations between the match and the average dollars contributed per contributing employee. If there is a correlation between a company's match structure and its average employee salary, then it is unclear whether the reported association is being driven by differences in the contribution rate as a fraction of salary or differences in salary. Below, I restrict discussion to studies that either report effects on the unconditional average contribution rate as a fraction of salary or whose reported results allow the reader to infer at least the sign of this unconditional average effect.

Studies using across-plan variation with no instrumental variable correction have found widely differing results on how match generosity affects unconditional average contribution rates. The United States General Accounting Office (1997), Clark and Schieber (1998), and Huberman et al. (2007) find a positive relationship. Basset et al. (1998) find no relationship. Clark et al. (2000) find a negative relationship. Mitchell et al. (2007) find that increases in the match rate on the first $3 \%$ of salary raise average contribution rates, but increases in the match rate on the next $3 \%$ salary contributed (i.e., the third to sixth percent of salary contributed) have no effect, and increases in the match rate on the next $2 \%$ of salary contributed (i.e., the sixth to eighth percent of salary contributed) lower average contribution rates. Because the measure of match generosity and the 
sampled population vary across studies, their differing results are not necessarily in conflict with each other.

Using within-firm variation at one company, Kusko et al. (1998) find that a more generous match rate has an extremely modest positive effect on the average contribution rate. As the match rate on the first $6 \%$ of income contributed changes from $65 \%$ to $150 \%$ to $139 \%$ to $0 \%$ within the course of four years, the average contribution rate moves from $5.0 \%$ to $5.3 \%$ to $5.2 \%$ to $4.9 \%$. Due to employee inertia, these responses to highfrequency match fluctuations may differ significantly from the long-run response to a permanent match. Choi et al. (2002) study a company with a 50\% match rate that increased its match threshold in January 1997 from 5\% to 7\% of income for union employees and from $6 \%$ to $8 \%$ of income for management employees. Figure 1 shows that there is an immediate response in the month of the change: a 3.7 percentage point drop in the fraction of participants contributing 5 to $6 \%$, matched by a 3.4 percentage point increase in the fraction of participants contributing 7 to $8 \%$. But the fraction of participants at 5 to $6 \%$ continues to drift downwards afterwards, and the fraction of participants at 7 to $8 \%$ continues to drift upwards. By the end of the sample period, three years after the change, the fraction of participants at 5 to $6 \%$ has fallen by 19 percentage points relative to where it was before the threshold change and the fraction of participants at 7 to $8 \%$ has risen by 13 percentage points, with no sign of the drifts decelerating. The number of participants contributing above the new match threshold does not fall, indicating that the income effect induced by the match is weak. This suggests that more generous matches should generally increase the average contribution rate.

In the Duflo et al. (2006) IRA experiment, the average contribution (including zeroes) rises from $\$ 22.20$ to $\$ 85.10$ to $\$ 154.90$ as the match rate rises from $0 \%$ to $20 \%$ to $50 \%$. These amounts correspond to only a tiny fraction of the subjects' average income of approximately $\$ 44,000$, but the one-time take-it-or-leave-it nature of the match makes it inappropriate to extrapolate these effect sizes to the 401(k) context. 


\section{Inertia in $401(\mathrm{k})$ plan contribution rates and its cures}

\section{A. Automatic enrollment versus opt-in enrollment}

One of the most striking characteristics of $401(\mathrm{k})$ employee contribution rates is their high level of inertia at the status quo. A consequence of this inertia is that changing the status quo, or default, can dramatically affect contribution rates without incurring the expense of offering a match.

Traditionally, enrollment in a 401(k) operated on an opt-in basis: if the employee took no action, then she was not enrolled in the 401(k). Madrian and Shea (2001) is the seminal paper studying what happens when a company changes its 401(k) default for new hires from non-enrollment to enrollment. Under the new regime, new hires who did not opt out within 30 days of hire were automatically enrolled in the 401(k) contributing 3\% of their income to a money market fund. Madrian and Shea (2001) focus on outcomes fifteen months after the introduction of automatic enrollment. Choi et al. (2004) study the longer-horizon effects of automatic enrollment at the Madrian and Shea (2001) company plus two others that switched from a $0 \%$ contribution rate default to either a $2 \%$ or $3 \%$ of income contribution rate default.

Figure 2 shows the fraction of employees that have ever contributed to the $401(\mathrm{k})$ at each level of job tenure at one of the Choi et al. (2004) companies. (Results are qualitatively similar at the other companies.) Those with a zero default gradually move to a positive contribution rate, but only $71 \%$ of these employees have ever contributed four years after hire. In contrast, participation jumps to $92 \%$ within four months of hire when enrollment is the default, and $99 \%$ of these employees have contributed at least once at four years of tenure. Automatically enrolled employees usually do not stop contributing to the plan once enrolled. At any given tenure level, only 7-9\% of employees subject to automatic enrollment are not contributing. Instead, employees subject to automatic enrollment are disproportionately likely to remain at the default contribution rate. Seventyfour percent are at the $2 \%$ default contribution rate four months after hire, and although this number slowly falls over time, $43 \%$ are still at the default contribution rate four years after hire. In contrast, $2 \%$ was chosen as the contribution rate by less than $20 \%$ of participants who were not subject to automatic enrollment. The mass at $2 \%$ under automatic enrollment comes not only from employees who would have otherwise been at $0 \%$, but 
also from employees who otherwise would have contributed at a higher rate. Therefore, automatic enrollment at a low default contribution rate only weakly raises the average contribution rate.

Adoption of automatic enrollment has risen rapidly. Only 5\% of new Vanguard plan enrollees in 2005 were in plans with automatic enrollment, versus 62\% in 2013. Automatic enrollment companies typically choose a low default contribution rate. Vanguard (2014) reports that in $2013,51 \%$ of the DC plans it administers had a $3 \%$ default, and another $14 \%$ had a lower default. Low defaults coupled with the rapid spread of automatic enrollment have created the recent drop in the average contribution rate conditional on participation even as participation rates have risen in the Vanguard universe. This pattern shows up in the aggregate U.S. data as well (Copeland 2013). The cost of employer matching contributions is a major reason why companies do not choose higher defaults (Steyer 2014; T. Rowe Price 2014). Although these costs could be avoided by reducing the generosity of the matching formula, companies may be reluctant to do so for fear of negative employee reactions.

A higher default contribution rate would not come at the cost of lower participation rates. Beshears et al. (2009) find that enrollment in the 401(k) plan they study does not fall when the default contribution rate is raised from $3 \%$ to $6 \%$. Thaler and Benartzi (2004) study a program that automatically increases contribution rates once a year-that is, a dynamic default. Among those who opt into auto-escalation, subsequent attrition from the program is quite low, resulting in extremely high contribution rates after several years. Benartzi et al. (2012) find that participation rates in auto-escalation rise dramatically from $27 \%$ to $83 \%$ when auto-escalation becomes the default. On the strength of this evidence, in 2013, 69\% of Vanguard-administered DC plans with automatic enrollment also by default enrolled employees in auto-escalation.

Defaults may be so powerful because multiple mechanisms act in concert to keep people at the status quo. Samuelson and Zeckhauser (1988) discuss several that may be relevant for the $401(\mathrm{k})$ contribution rate domain. First, moving from the default requires paying a transaction cost. Because there is no monetary transaction cost associated with changing one's 401(k) contribution rate and the effort required is minimal relative to the likely benefits, transaction costs alone seem insufficient to explain persistence at the de- 
fault for over four years. However, minor transactions costs can lead to significant delays in action if the individual is present-biased (Strotz 1956; Laibson 1997; O'Donoghue and Rabin 1999), causing him to put too much weight on the present disutility of acting and not enough weight on the resulting future utility gain. If individuals expect their future selves to not be present-biased, then procrastination can be particularly severe, since delay today is perceived to be less costly than it actually is due to over-optimism that the future self will act promptly. Consistent with the existence of naiveté about present bias, Choi et al. (2002) find that among survey respondents who said their savings rate was too low and that they planned to raise their $401(\mathrm{k})$ contribution rate in the next few months, only $14 \%$ actually did so within four months of the survey. Choi et al. (2003) and Carroll et al. (2009) model default effects as arising from a present-biased agent with a quasihyperbolic time discount function drawing a stochastic opt-out cost each period and deciding whether to pay this cost to move to his optimal contribution rate. The agent's solution is to opt out when he draws any cost below an endogenously determined threshold. The models predict that agents who opt out of the default sooner tend to move further away from the default, since the more costly staying at the default is, the higher the transaction cost one is willing to pay to move away from it. Carroll et al. (2009) provide empirical support for this prediction.

Second, employees may reason that the default action is recommended by their employer, causing them to remain at the default. There is no direct evidence of such an endorsement effect at work in $401(\mathrm{k})$ contribution rates, but there is evidence of it in closely related domains. Madrian and Shea (2001) find that after automatic enrollment was implemented for new hires, seasoned employees not subject to automatic enrollment were more likely to allocate some money to the default money market fund, suggesting that they inferred something from the asset allocation default that applied only to their coworkers. Notably, however, Beshears et al. (2009) remark that these seasoned employees were not more likely to move to the contribution rate default, suggesting that the endorsement effect is weaker for contribution rate defaults than for asset allocation defaults. Brown et al. (2011) survey employees of Illinois public universities, who had to make an irrevocable choice among three pension plans. Twenty percent of those who were auto- 
matically enrolled in the default DB plan said they allowed this to happen because they believed that it was the recommended choice by the pension administrator.

Third, loss aversion (Kahneman and Tversky 1979) may keep people at the status quo. A loss-averse agent considers a loss relative to a reference point to be more painful than an equivalent-sized gain relative to the reference point is pleasurable. If the status quo is the reference point and there is uncertainty about the value of opting out, then the agent will be biased towards remaining at the status quo. This phenomenon is also referred to as the endowment effect (Thaler 1980). Closely related is regret avoidance; Kahneman and Tversky (1982) argue that individuals regret bad consequences of action more than bad consequences of inaction.

Fourth, the default may serve as an anchor (Tversky and Kahneman 1974). Many laboratory experiments have shown that when people make judgments and estimations after having been shown an arbitrary value, their final answer is biased towards this arbitrary anchor. Consistent with anchoring having the ability to influence 401(k) contribution rates, Choi et al. (2012) and Goda et al. (2012) show in randomized field experiments that one can raise contribution rates by merely mentioning an arbitrary higher rather than an arbitrary lower contribution amount in communications sent to employees about their retirement savings plan.

Fifth, due to bounded rationality, individuals may consider only a subset of the possible contribution rates. If contribution rates outside the consideration set are never chosen and the status quo is disproportionately likely to be in the consideration set, then the status quo is disproportionately likely to be chosen. The strongest evidence that individuals consider only a subset of possible contribution rates comes from the observation that chosen contribution rates are especially prone to be a multiple of five such as $5 \%$, $10 \%$, or 15\% (Choi et al. 2002, 2006; Benartzi and Thaler 2007) —amounts that have no special normative economic significance.

Sixth, once an individual has been moved to the default, she may persist at it longer because of cognitive dissonance. The theory of cognitive dissonance predicts that once an individual finds herself at the default, she is inclined to rationalize the outcome by coming to believe that she prefers the default anyway. 
A seventh possible mechanism not mentioned by Samuelson and Zeckhauser (1988) is inattention or ignorance. If one is not aware that the default is being implemented, then one cannot opt out of it. Brown, Farrell, and Weisbenner (2011) find that 19\% of University of Illinois employees who were automatically enrolled in the default pension plan report being unaware that they could make a choice among pension plans. Such unawareness could be rational given information processing capacity constraints (Sims 2006).

\section{B. Active choice enrollment}

In DC plans where employees can choose their own contribution rate and there is a default, contribution rates cluster at that default. This is undesirable if the population's optimal contribution rate distribution is not tightly centered around the default. However, as long as the employee has the option to not actively choose a contribution rate, instituting a default is unavoidable because some contribution rate must be implemented when the employee remains passive. Only by compelling an active choice can there be no default.

Carroll et al. (2009) study a company that implemented such an active choice enrollment regime. Employees were required to actively choose a contribution rate (which could be zero) within thirty days of hire. Three months after hire, $69 \%$ of employees were contributing to the 401(k). Later, the company switched to an opt-in enrollment regime for new hires, and the participation rate at three months of tenure fell by 28 percentage points. This difference persisted for years; at 24 months of tenure, the participation rate gap was 17 percentage points, and at 42 months of tenure, it was 5 percentage points.

The difference between the two regimes indicates that the low initial participation rate under opt-in enrollment was not due to liquidity constraints or other classical reasons not to save in the $401(\mathrm{k})$. The contribution rate distribution at three months of tenure under the active choice regime is nearly identical to the contribution rate distribution at 30 months of tenure under the opt-in enrollment regime. It appears that without a deadline, many employees simply don't get around to enrolling promptly in the 401(k). 


\section{Choice overload and simplification}

An alternative to overcoming inertia by simply banning it, as an active choice regime does, is to reduce the costs of opting out of the default. Since there are no monetary costs to opting out, the largest costs are probably the cognitive cost of figuring out what choice to opt out to and the logistical effort cost of the opt-out process. Sethi-Iyengar et al. (2004) find that in a cross-section of 647 401(k) plans with default non-enrollment, those with more options in the investment menu have lower participation rates. For every additional ten funds, the participation rate is lower by 1.5 to 2 percentage points. They interpret this relationship as arising from employees being put off by the complexity of the asset allocation choice they must make in order to opt into the plan.

Choi et al. (2011) and Beshears et al. (2013) study Quick Enrollment, an intervention that makes the enrollment process cognitively simpler at firms with default nonenrollment. Treated employees could enroll in the $401(\mathrm{k})$ at a pre-selected contribution rate and asset allocation by using the Quick Enrollment form. Instead of grappling with the multidimensional problem of which of the myriad possible contribution rate and asset allocation combinations is optimal, employees receiving the Quick Enrollment form could reduce the problem to a binary choice: Do I prefer my status quo or the pre-selected option? In addition, the Quick Enrollment forms may have been a more convenient way to enroll in the 401(k) than the standard channel. By comparing enrollment behavior when Quick Enrollment is used versus not used within the same companies, Choi et al. (2011) and Beshears et al. (2013) estimate that Quick Enrollment raises participation rates by 10 to 20 percentage points.

\section{Financial literacy}

Many researchers have documented that Americans have low levels of financial literacy (e.g., Brobeck 1990; Bernheim 1998; Hilgert et al. 2003; Lusardi and Mitchell 2007). For example, only $78 \%$ of U.S. adults know that $\$ 100$ invested at a $2 \%$ annual interest rate will grow to more than $\$ 102$ at the end of five years, and only $53 \%$ know that a stock mutual fund provides a safer return than a single stock (Hastings, Madrian, and Shea 2013). Financial literacy seems likely to decrease the cognitive cost of making active contribution choices in one's pension. In a time where the default action was almost 
universally not to be participating in a DC pension, Hilgert et al. (2003) find that participation in 401(k) plans and IRAs is increasing in financial literacy, and Bernheim (1998) documents that financial literacy is positively correlated with retirement wealth accumulation. Lusardi and Mitchell (2007) argue that financial literacy makes people more likely to form a financial plan, and planning increases wealth accumulation (see also Ameriks, Caplin, and Leahy 2003).

The correlation between financial literacy and DC savings need not be due to a causal channel from literacy to saving. People who save more may find it more worthwhile to acquire financial literacy because they have more assets to manage, so the gains to financial literacy are larger. Or a third characteristic such as one's time discount rate may cause both higher saving and greater acquisition of financial knowledge (Meier and Sprenger 2013). Finding exogenous variation in financial literacy in order to identify the causal direction is challenging.

Bernheim and Garrett (2003) study a cross-section of 2,055 individuals to identify the effect of financial education provided in the workplace. Although the employer's decision to provide financial education is not exogenous, they argue that employers are more likely to provide financial education to workforces that are predisposed to save little, so comparing outcomes between employees who have education offered to them versus those who do not will underestimate the effect of financial education. They find that the $401(\mathrm{k})$ participation rate is 12.1 percentage points higher, the median retirement saving rate (including non-401(k) savings) is 1.1 percentage points higher, and the median $401(\mathrm{k})$ balance is $\$ 2,789$ higher when the individual's employer offers financial education. Financial education appears to have spillover effects as well; the employee's spouse's $401(\mathrm{k})$ participation rate is 9.2 percentage points higher when the employer offers financial education.

Bernheim (1998) analyzes a survey that elicited current and five-year-ago 401(k) participation rates at 40 companies, which allows him to control for firm fixed effects and thus eliminate some of the bias created by the endogeneity of financial education. He finds that offering workplace financial education increases the 401(k) participation rate by 12 percentage points. Bayer, Bernheim, and Scholz (2009) are also able to control for firm fixed effects in a two-year panel of a few hundred employers. Without controlling 
for firm fixed effects, frequent educational seminars are associated with an 8.2 percentage point increase in the $401(\mathrm{k})$ participation rate and a 0.7 percentage point increase in the average $401(\mathrm{k})$ contribution rate. Controlling for firm fixed effects, the point estimates are similar-a 7.7 percentage point increase in participation and a 0.4 percentage point increase in the average contribution rate-but they are no longer statistically significant at the 5\% level. The effects are stronger in magnitude and statistical significance for lower-paid employees.

Skimmyhorn (2013) exploits the staggered rollout of an eight-hour personal financial management course across thirteen U.S. Army bases to identify the course's effect on financial outcomes. He finds that the course increases the probability of contributing to the Thrift Savings Plan by 15 percentage points one year after enlistment in the Army and 8 percentage points four years after enlistment. However, not all of this effect can be attributed to an increase in financial literacy, since the course also provided assistance in enrolling in the Thrift Savings Plan. The average contribution amount increases modestly — \$20 per month one year after enlistment and a statistically insignificant $\$ 7$ per month four years after enlistment-although these represent large proportional increases relative to an average contribution of $\$ 30$ per month or less among enlistees who did not receive the course.

\section{Peer effects}

Duflo and Saez (2002) find that among employees of one large university, the 403(b) enrollment decisions of one's colleagues in the same department influence one's own decision to enroll. Like nearly all empirical studies of peer effects, they must address the possibility that peers exhibit similar behavior not because of mutual influence, but because they share a common unobservable factor (Manski 1993). Duflo and Saez do so by using the wage and tenure distribution of coworkers in one's department as instrumental variables for their 403(b) participation decision. They estimate that a 10 percentage point increase in one's coworkers' participation rate increases one's own participation probability by 2 percentage points. In addition, one's participation is affected only by coworkers who are demographically similar to oneself. 
Duflo and Saez (2003) run a field experiment at the same university to address the possibility that the Duflo and Saez (2002) instruments for coworker participation are invalid. They give a random sample of employees who are not participating in the 403(b) a $\$ 20$ incentive to attend a benefits information fair organized by the university. They find that incentivized employees are 23 percentage points more likely to attend the fair than non-participating workers in departments with no incentivized employees (the control group). Consistent with the existence of a spillover effect, unincentivized nonparticipants who have incentivized coworkers in their own department are 10 percentage points more likely than the control group to attend the fair. 403(b) participation among incentivized employees is 1.4 percentage points higher than the control eleven months after the fair. The participation rate among unincentivized employees with incentivized departmental coworkers is also higher. Surprisingly, the treatment effect on this latter group has almost exactly the same magnitude: 1.3 percentage points.

Beshears et al. (2014) analyze a field experiment that sent a randomly selected subset of low-saving employees at one firm information about either what fraction of coworkers in their age bracket are participating in the $401(\mathrm{k})$ or what fraction of $401(\mathrm{k})$ participants in their age bracket are contributing at least $6 \%$ of their income to the plan. They document that seeing peer information decreases 401(k) saving among nonparticipants with a non-enrollment default, and the higher the reported peer number is, the more negative the effect becomes, suggesting that the reaction is not driven by downward revisions in beliefs about peer contribution rates. The perverse effect is concentrated among poorer employees, suggesting that discouragement from upward social comparisons plays a role.

\section{Mental accounting}

Card and Ransom (2011) study how the psychological non-fungibility of contributions with different labels_-i.e., mental accounting (Thaler 1985, 1990, 1999)_affects 403(b) contribution rates. Many universities have mandatory contributions for each employee to a DC plan. A portion of these mandatory contributions is called an "employer contribution," while the remainder is called an "employee contribution." Employees can also make supplementary contributions to a 403(b) plan. According to classical theory, 
mandatory employer contributions should crowd out supplementary contributions at the same rate as mandatory employee contributions do, since the two types of contributions are economically equivalent. Using cross-sectional variation in the structure of the mandatory contribution at 77 universities, Card and Ransom find that a \$1 mandatory employee contribution crowds out supplemental contributions by 60 to 80 cents, while a $\$ 1$ mandatory employer contribution crowds out supplemental contributions by only half as much. They hypothesize that the differential crowd-out occurs because mandatory employee contributions and supplementary contributions are both drawn from the "wages" mental account, whereas mandatory employer contributions are drawn from a different mental account.

Chetty et al. (2013) use data covering the entire Danish population to show nonfungibility in a much larger sample. In Denmark, most jobs pay a fixed proportion of the worker's wages into a DC plan, but this proportion varies across jobs. Workers can also save in the analogue of an IRA that is separate from the employer pension. Chetty et al. find that when a worker switches to a job where the employer pension contribution rate is $1 \%$ of income higher, his contributions to the IRA-equivalent fall by only $0.05 \%$ to $0.06 \%$ of income in the year of the switch, and this lack of fungibility cannot be explained by workers being constrained by the zero lower bound on IRA-equivalent contributions.

\section{Personal experience}

Psychological and experimental economic evidence indicates that past personal experience exerts a powerful influence on decisions that can conflict with forwardlooking models and Bayesian forecasts (Nisbett and Ross 1980; Weber et al. 1993; Erev

and Roth 1998; Charness and Levin 2003; Hertwig et al. 2004). Choi et al. (2009) find a similar dynamic in 401(k) contributions. In a panel of employees at five companies, they find that workers who experience 401(k) returns with high mean and low variance increase their $401(\mathrm{k})$ contribution rates by a greater amount than workers who experienced less attractive returns. After controlling for investor fixed effects, aggregate time-series shocks, income effects, and the percent of the 401(k) portfolio allocated to each broad asset class, they estimate that a one standard deviation increase in the rate of return expe- 
rienced in a year increases $401(\mathrm{k})$ contribution rates by 0.13 percentage points at the end of the same year, while a one standard deviation decrease in the return variance experienced increases $401(\mathrm{k})$ contribution rates by 0.16 percentage points in the first year and another 0.34 percentage points by the end of the second year.

\section{Future research directions}

DC pension contributions ultimately matter because they will fund future consumption. Therefore, it is important to understand how they interact with non-DC saving. To what extent do DC contributions represent new saving versus the shifting of saving from outside the DC pension to inside the DC pension? Unfortunately, the literature has been unable to provide definitive evidence on the broad question of whether 401(k) and IRA savings in general are truly new savings (Bernheim 2002). Now that employers and governments are actively using tools such as matches and automatic enrollment to alter DC contribution outcomes, the more specific question of how each of these interventions' marginal impact on DC contributions translates into marginal impacts on total savings comes to the fore as well. Chetty et al. (2013) is an important recent contribution in this area. Because they have a panel of comprehensive wealth data on millions of Danes, they are able to produce more convincing estimates of total wealth impacts. They find that 99\% of the increase in pension contributions induced by tax subsidies is due to saving shifting from other accounts, while a $\$ 1$ increase in the employer (non-matching) contribution to the worker's pension results in an $\$ 0.80$ increase in the worker's total saving.

DC contributions can be offset not only by reduced saving outside the DC plan, but also by pre-retirement withdrawals from the pension. Argento et al. (2015) report that for every dollar contributed to the DC system in 2010 by those under the age of 55, 40 cents leaked out to this group as a pre-retirement withdrawal in the same year. The extent to which these withdrawals are suboptimal choices and how illiquid pension balances should ideally be before retirement are open questions. 


\section{Literature cited}

Ameriks J, Caplin A, Leahy J. 2003. Wealth accumulation and the propensity to plan. $Q$. J. Econ. 118:1007-46

Andrews ES. 1992. The growth and distribution of 401(k) plans. In Trends in Pensions 1992, ed. JA Turner, DJ Beller, pp. 149-76. Washington, DC: U.S. Department of Labor

Argento R, Bryant VL, Sabelhaus J. 2015. Early withdrawals from retirement accounts during the Great Recssion. Contemporary Econ. Policy 33:1-16

Bassett WF, Fleming MJ, Rodrigues AP. 1998. How workers use 401(k) plans: The participation, contribution, and withdrawal decisions. Natl. Tax J. 51:263-89

Bayer PJ, Bernheim BD, Scholz JK. 2009. The effects of financial education in the workplace: Evidence from a survey of employers. Econ. Inquiry 47:605-24

Benartzi S, Peleg E, Thaler RH. 2012. Choice architecture and retirement savings plans. In The Behavioral Foundations of Public Policy, ed. E Shafir, pp. 245-263. Princeton: Princeton Univ. Press.

Benartzi S, Thaler RH. 2007. Heuristics and biases in retirement savings behavior. $J$. Econ. Perspect. 21:81-104

Bernheim BD. 1998. Financial illiteracy, education, and retirement saving. In Living with Defined Contribution Pensions: Remaking Responsibility for Retirement, ed. OS Mitchell, SJ Schieber, pp. 38-68. Philadelphia: Univ. Pennsylvania Press

Bernheim BD. 2002. Taxation and saving. In Handbook of Public Economics, Volume 3, ed. AJ Auerbach, M Feldstein, pp. 1173-249. Amsterdam: Elsevier Science B.V.

Bernheim BD, Garrett DM. 2003. The effects of financial education in the workplace: evidence from a survey of households. J. Public Econ. 87:1487-519

Beshears J, Choi JJ, Laibson D, Madrian BC. 2009. The importance of default options for retirement saving outcomes: Evidence from the United States. In Lessons from Pension Reform in the Americas, ed. SJ Kay, T Sinha, pp. 59-87. Oxford: Oxford Univ. Press

Beshears J, Choi JJ, Laibson D, Madrian BC. 2013. Simplification and saving. J. Econ. Behav. and Organization 95:103-45 
Beshears J, Choi JJ, Laibson D, Madrian BC. 2014. The effect of providing peer information on retirement savings decisions. J. Finance. In press.

Brobeck S. 1990. U.S. Consumer Knowledge: Results of a Nationwide Test. Washington, DC: Consum. Fed. Am.

Brown JR, Farrell AM, Weisbenner SJ. 2011. The downside of defaults. Work. Pap., Univ. Illinois Urbana-Champaign

Card D, Ransom M. 2011. Pension plan characteristics and framing effects in employee savings behavior. Rev. Econ. and Statistics 93:228-243

Carroll GD, Choi JJ, Laibson D, Madrian BC, Metrick A. 2009. Optimal defaults and active decisions. Q. J. Econ. 124:1639-74

Charness G, Levin D. 2003. When optimal choices feel wrong: A laboratory study of Bayesian updating, complexity, and affect. Am. Econ. Rev. 95:1300-09

Chetty R, Friedman JN, Leth-Petersen S, Nielsen TH, Olsen T. 2013. Active vs. passive decisions and crowd-out in retirement savings accounts: Evidence from Denmark. $Q$. J. Econ. In press

Choi JJ, Haisley E, Kurkoski J, Massey C. 2012. Small cues change savings choices. Work. Pap., Natl. Bur. Econ. Res.

Choi JJ, Laibson D, Madrian BC. 2010. \$100 bills on the sidewalk: Suboptimal investment in 401(k) plans. Rev. Econ. Stat. 93:748-63

Choi JJ, Laibson D, Madrian BC. 2011. Reducing the complexity costs of 401(k) participation through Quick Enrollment ${ }^{\mathrm{TM}}$. In Developments in the Economics of Aging, ed. DA Wise, pp. 57-82. Chicago: Univ. Chicago Press

Choi JJ, Laibson D, Madrian BC, Metrick A. 2002. Defined contribution pensions: Plan rules, participant decisions, and the path of least resistance. In Tax Policy and the Economy, Volume 16, ed. JM Poterba, pp. 67-114. Cambridge, MA: MIT Press

Choi JJ, Laibson D, Madrian BC, Metrick A. 2003. Optimal defaults. Am. Econ. Rev. 93:180-85

Choi JJ, Laibson D, Madrian BC, Metrick A. 2004. For better or for worse: Default effects and 401(k) savings behavior. In Perspectives in the Economics of Aging, ed. DA Wise, pp. 81-121. Chicago: Univ. Chicago Press 
Choi JJ, Laibson D, Madrian BC, Metrick A. 2006. Saving for retirement on the path of least resistance. In Behavioral Public Finance: Toward a New Agenda, ed. EJ McCaffrey, J Slemrod, pp. 304-51. New York: Russell Sage Foundation

Choi JJ, Laibson D, Madrian BC, Metrick A. 2009. Reinforcement learning and savings behavior. J. Finance 64:2515-34

Clark RL, Goodfellow GP, Schieber SJ, Warwick D. 2000. Making the most of 401(k) plans: Who's choosing what and why? In Forecasting Retirement Needs and Retirement Wealth, ed. OS Mitchell, PB Hammond, AM Rappaport, pp. 95-138. Philadelphia: Univ. Pennsylvania Press

Clark RL, Schieber SJ. 1998. Factors affecting participation rates and contribution levels in 401(k) plans. In Living with Defined Contribution Pensions: Remaking Responsibility for Retirement, ed. OS Mitchell, SJ Schieber, pp. 69-97. Philadelphia: Univ. Pennsylvania Press

Copeland C. 2013. Retirement plan participation: Survey of Income and Program Participation (SIPP) data, 2012. EBRI Notes 34(8)

Duflo E, Gale W, Liebman J, Orszag P, Saez E. 2006. Saving incentives for low- and middle-income families: Evidence from a field experiment with $\mathrm{H} \& \mathrm{R}$ Block. Q. $J$. Econ. 121:1311-46

Duflo E, Saez E. 2002. Participation and investment decisions in a retirement plan: The influence of colleagues' choices. J. Public Econ. 85:121-48

Duflo E, Saez E. 2003. The role of information and social interactions in retirement plan decisions: Evidence from a randomized experiment. Q. J. Econ. 118:815-42

Dworak-Fisher K. 2011. Matching matters in 401(k) plan participation. Industrial Relations 50:713-37

Engelhardt GV, Kumar A. 2007. Employer matching and 401(k) saving: Evidence from the health and retirement study. J. Public Econ. 91:1920-43

Erev I, Roth AE. 1998. Predicting how people play games: Reinforcement learning in experimental games with unique, mixed strategy equilibria. Am. Econ. Rev. 88:84881

Even WE, Macpherson DA. 2005. The effects of employer matching in 401(k) plans. Industrial Relations 44:525-49 
Goda, GS, Manchester CF, Sojourner A. 2014. What will my account really be worth? An experiment on exponential growth bias and retirement saving. J. Public Econ. $119: 80-92$

Hastings JS, Madrian BC, Skimmyhorn WL. 2013. Financial literacy, financial education, and economic outcomes. Annu. Rev. Econ. 5:347-73

Hertwig R, Barron G, Weber EU, Erev I. 2004. Decisions from experience and the effect of rare events in risky choice. Psychological Science 15:534-39

Hilgert MA, Hogarth JM, Beverly SG. 2003. Household financial management: The connection between knowledge and behavior. Fed. Reserve Bull. 89(7):309-22

Holden S, Schrass D. 2013. The role of IRAs in U.S. households' saving for retirement, 2013. ICI Research Perspective 19(11)

Huberman G, Iyengar SS, Jiang W. 2007. Defined contribution pension plans: Determinants of participation and contributions rates. J. Financial Services Res. 31:1-32

Investment Company Institute. 2014. The U.S. Retirement Market, Second Quarter 2014. Washington D.C.: Investment Company Institute.

Kahneman D, Tversky A. 1979. Prospect theory: An analysis of decision under risk. Econometrica 47:263-92

Kahneman D, Tversky A. 1982. The psychology of preferences. Scientific Am. 246:16073

Kusko AL, Poterba JM, Wilcox DW. 1998. Employee decisions with respect to 401(k) plans. In Living with Defined Contribution Pensions: Remaking Responsibility for Retirement, ed. OS Mitchell, SJ Schieber, pp. 98-112. Philadelphia: Univ. Pennsylvania Press

Laibson D. 1997. Golden eggs and hyperbolic discounting. Q. J. Econ. 112:443-77

Lusardi A, Mitchell OS. 2007. Baby Boomer retirement security: The roles of planning, financial literacy, and housing wealth. J. Monetary Econ. 54:205-24

Madrian BC, Shea DF. 2001. The power of suggestion: Inertia in 401(k) participation and savings behavior. Q. J. Econ. 116:1149-87

Manski C. 1993. Identification of exogenous social effects: The reflection problem. Rev. Econ. Stud. 60:531-542 
Meier S, Sprenger C. 2010. Present-biased preferences and credit card borrowing. Am. Econ. J. Appl. Econ. 2(1):193-210

Mitchell OS, Utkus SP, Yang T. 2007. Turning workers into savers? Incentives, liquidity, and choice in 401(k) plan design. Natl. Tax J. 60:469-89

Nisbett RE, Ross LD. 1980. Human Inference: Strategies and Shortcomings of Social Judgment. Englewood Cliffs, NJ: Prentice Hall

O’Donoghue T, Rabin M. 1999. Doing it now or later. Am. Econ. Rev. 89:103-24

OECD. 2013. Pension Markets in Focus. Paris, France: OECD

Papke LE. 1995. Participation in and contributions to 401(k) pension plans: Evidence from plan data. J. Hum. Resour. 30:311-25

Papke LE, Poterba JM. 1995. Survey evidence on employer match rates and employee saving behavior in 401(k) plans. Econ. Letters 49:313-17

Poterba JM, Venti SF, Wise DA. 2010. The rise of 401(k) plans, lifetime earnings, and wealth at retirement. In Research Findings in the Economics of Aging, ed. DA Wise, pp. 271-304. Chicago: Univ. Chicago Press

Samuelson W, Zeckhauser R. 1988. Status quo bias in decision making. J. Risk and Uncertain. 1:7-59.

Sethi-Iyengar S, Huberman G, Jiang W. 2004. How much choie is too much? Contributions to 401(k) retirement plans. In Pension Design and Structure: New Lessons from Behavioral Finance, pp. 83-95, ed. OS Mitchell, SP Utkus. Oxford: Oxford Univ. Press

Sims CA. 2006. Rational inattention: Beyond the linear-quadratic case. Am. Econ. Rev. 96:158--163

Skimmyhorn W. 2013. Assessing financial education: Evidence from a personal financial management course. Work. Pap., United States Military Academy West Point

Steyer R. 2014. “Adoption of automatic enrollment slows down." Pensions \& Invest. (February 12).

http://www.pionline.com/article/20140212/ONLINE/140219961/adoption-of-autoenrollment-slows-down

Strotz RH. Myopia and inconsistency in dynamic utility maximization. Rev. Econ. Stud. 23:165-80. 
Thaler RH. 1980. Toward a positive theory of consumer choice. J. Econ. Behav. and Organization 1:39-60.

Thaler RH. 1985. Mental accounting and consumer choice. Marketing Science 4:199-214

Thaler RH. 1990. Anomalies: Saving, fungibility, and mental accounts. J. Econ. Perspect. 4:193-205

Thaler RH. 1999. Mental accounting matters. J. Behavioral Decis. Mak. 12:183-206

Thaler RH, Benartzi S. 2004. Save More Tomorrow: Using behavioral economics to increase employee saving. J. Polit. Econ. 112:S164-87

Thaler RH, Sunstein CR. 2008. Nudge: Improving Decisions About Health, Wealth, and Happiness. New Haven: Yale Univ. Press

T. Rowe Price. 2014. Getting beyond the ordinary-Managing plan costs in automatic programs. Baltimore: T. Rowe Price Group

Tversky A., Kahneman D. 1974. Judgment under uncertainty: Heuristics and biases. Science 185:1124-31

United States Department of Labor. 2013. National Compensation Survey: Employee benefits in the United States, March 2013. Washington, DC: U.S. Department of Labor. http://www.bls.gov/ncs/ebs/benefits/2013/ebb10052.pdf

United States General Accounting Office. 1997. 401(k) pension plans: Loan provisions enhance participation but may affect income security for some. Washington, DC: United States General Accounting Office

Vanguard. 2014. How America saves 2014: A report on Vanguard 2013 defined contribution plan data. Valley Forge, PA: Vanguard Group.

Weber EU, Böckenholt U, Hilton DJ, Wallace B. 1993. Determinants of diagnostic hypothesis generation: Effects of information, base rates, and experience. J. Exp. Psychology: Learning, Mem., and Cognition 19:1151-64 


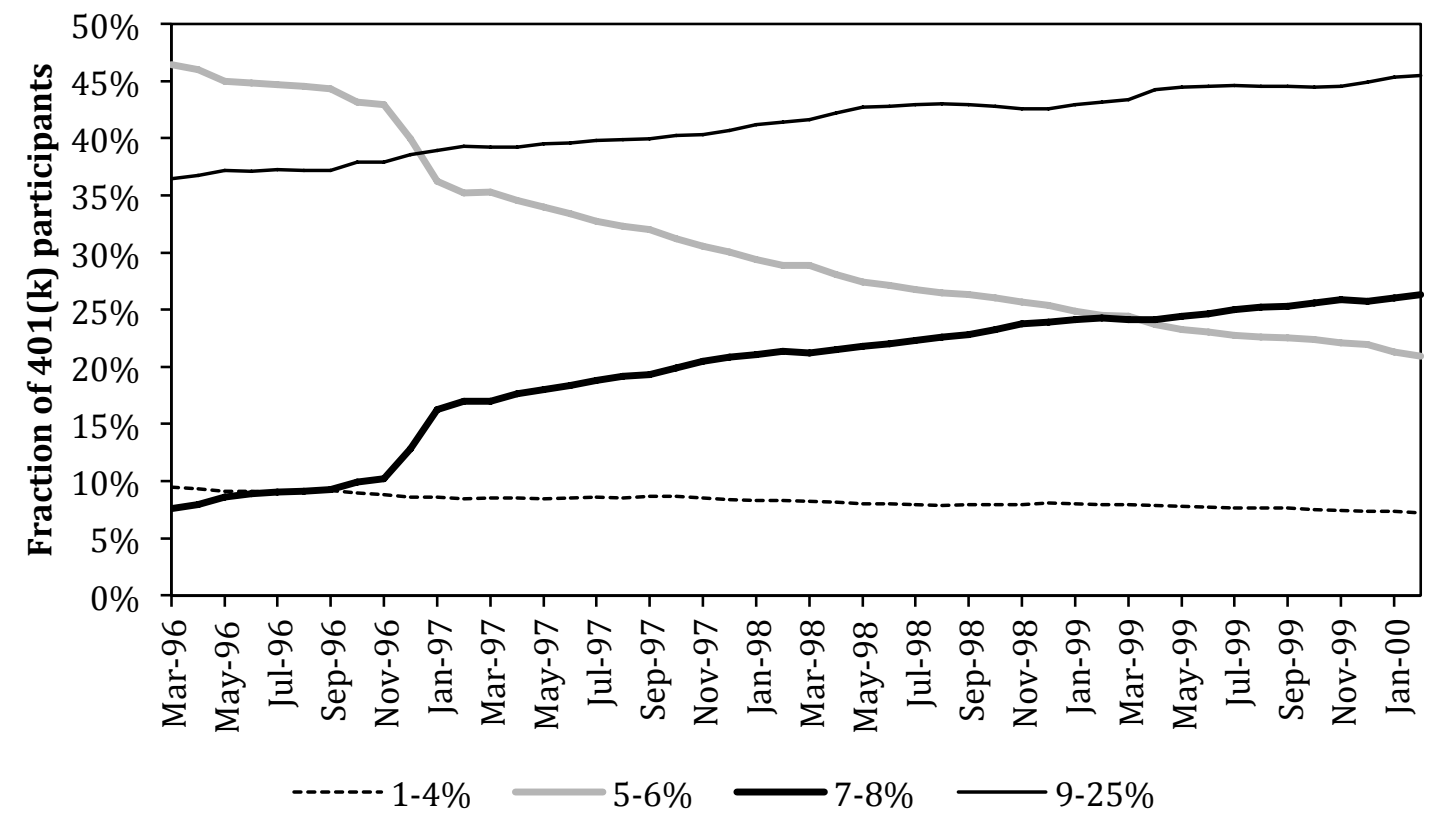

Figure 1. Distribution of 401(k) participant contribution rates at one company following a match threshold increase from 5\% to $7 \%$ of income (union employees) or $6 \%$ to $8 \%$ of income (management employees). Source: Choi et al. (2002)

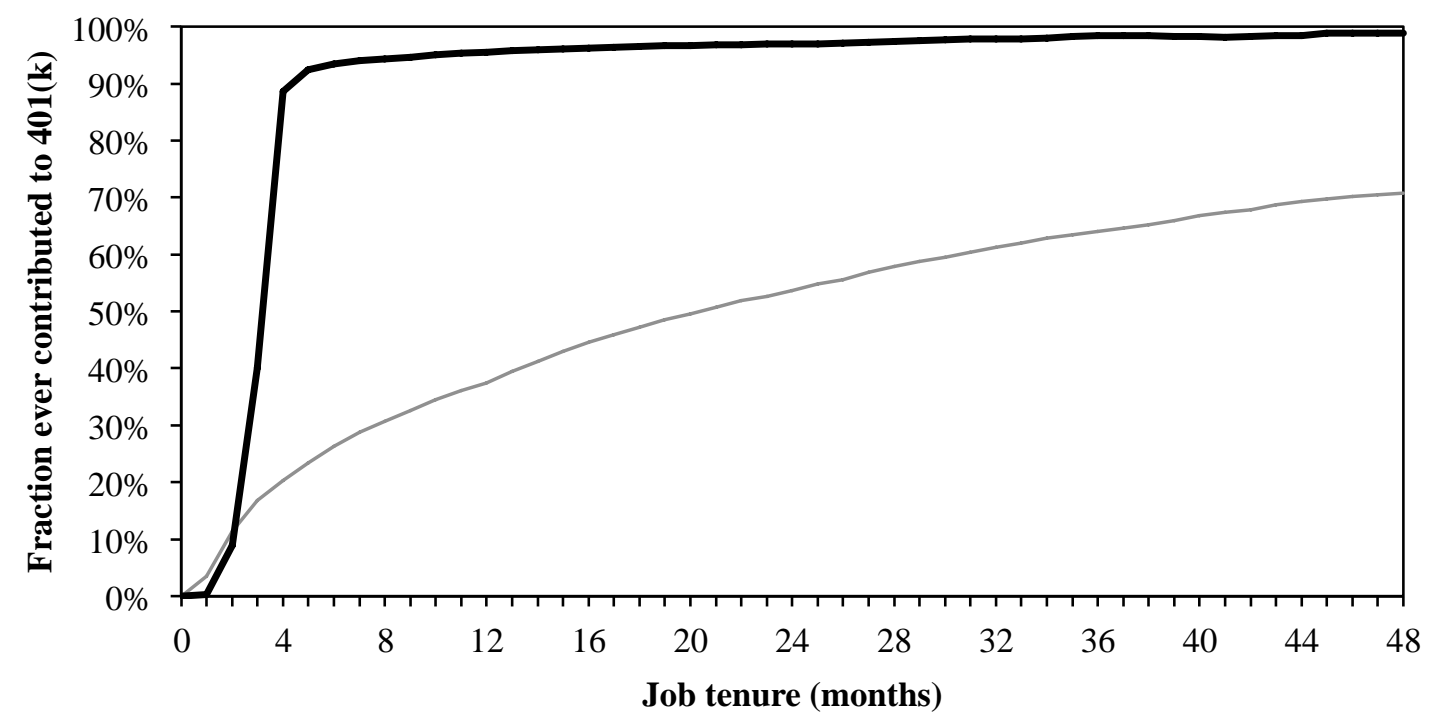

— Non-enrollment default —Automatic enrollment

Figure 2. Fraction of employees hired under automatic enrollment or a non-enrollment default who have ever contributed to the $401(\mathrm{k})$ plan, by job tenure, at one company. Source: Choi et al. (2004) 